\title{
INVESTIGATION OF THERMAL AND STRUCTURAL PROPERTIES OF NATURAL AND ION-EXCHANGED ANALCIME
}

\author{
Meryem SAKIZCI* \\ Physics Department, Faculty of Science, Anadolu University, Eskişehir, TURKEY
}

\begin{abstract}
In this study, the thermal and structural properties of natural analcime zeolite obtained from the Çanakkale-KüçükkuyuAyvack region and its cationic forms ( $\mathrm{HA}, \mathrm{FeA}, \mathrm{AgA}$ and $\mathrm{CuA})$ were characterized using a range of methods. These included X-ray fluorescence (XRF), X-ray diffraction (XRD), thermogravimetric analysis (TG), differential thermogravimetric analysis (DTG), differential thermal analysis (DTA) and specific surface area measurement techniques. Cationic forms were prepared by using $1 \mathrm{M} \mathrm{HCl}, 1 \mathrm{M} \mathrm{Fe}\left(\mathrm{NO}_{3}\right)_{3} .9 \mathrm{H}_{2} \mathrm{O}, 1 \mathrm{M} \mathrm{AgNO}_{3}$ and $1 \mathrm{M} \mathrm{Cu}\left(\mathrm{NO}_{3}\right)_{2} \cdot 3 \mathrm{H}_{2} \mathrm{O}$ solutions. Quantitative XRD analysis showed that the natural zeolite was mainly composed of analcime accompanied by quartz, feldspar, montmorillonite and amorphous substances. AgA and HA samples showed different thermal and structural behaviors due to their rearranged crystal structure and chemical composition. Adsorption properties of samples were determined by using adsorption isotherms and specific surface areas obtained by the Brunauer-Emmet-Teller (BET) method. The specific surface areas of the ion-exchanged analcime zeolites were found to be higher in comparison to natural analcime. Among all the modified forms, it was found that the $\mathrm{H}$ form of the analcime sample has the largest surface area HA $\left(41.88 \mathrm{~m}^{2} / \mathrm{g}\right)$.
\end{abstract}

Keywords: Zeolite, Analcime, N2 Adsorption, XRD, TG-DTG-DTA

\section{INTRODUCTION}

Zeolites are defined as alumina silicates of alkali and earth alkali metals that have a crystal structure. The smallest structural unit of any zeolite crystal is the $\mathrm{SiO}_{4}$ or $\mathrm{AlO}_{4}$ tetrahedron. Natural zeolites are used in many fields like adsorption, catalysis, the building industry, in agriculture and earth enrichment [1]. Analcime, which has the chemical formula $\mathrm{NaAlSi}_{2} \mathrm{O}_{6} \cdot \mathrm{H}_{2} \mathrm{O}$ and a cubic crystal structure, is a hydrated, sodium aluminosilicate mineral $[2,3]$. The crystal structure of analcime was determined by Taylor [2] and refined by Calleri and Ferraris [4], Knowles et al. [5], Ferraris et al. [6] and Pechar [7]. Mazzi and Galli [8] also demonstrated tetragonal and orthorhombic analcime structures. Analcime is also known as analcite. The name analcime comes from the Greek word analkis, which means "weak" or "without power". Analcime includes trace amounts of potassium and calcium. Although they are classified as zeolite minerals, their structures and chemical properties are more similar to leucite-type feldspathoids. The $\mathrm{Si} / \mathrm{Al}$ ratio changes between 1.8 and 2.8. Analcime can be found in basalt and other alkaline volcanic rocks. The crystal structure of analcime is composed of 4-member ( $\mathrm{Si}, \mathrm{Al}$ )-O rings, which are comprised of chains in three dimensions. Analcime (ANA) structures formed in this way include channels parallel to $\langle 110\rangle$ that are connected to 8-member tetragonal rings. Unlike the big extraframework positions and channel openings which are commonly found in many zeolites - like clinoptilolite - channels in analcime are pretty small, with openings $\sim 1.6 \AA \times 4.2 \AA[9,10]$. These small channels affect both the cation exchange behavior and dehydration/hydration behavior of analcime. This type of channel formation enables many structural changes, like structural deformation, channel collapse and ionic movements. Natural and synthetic analcime zeolites cannot be used as molecular sieves and catalyzers because the channels in its crystal structure are pretty narrow. In zeolites with small pores, like analcime, only small molecules (e.g. $\mathrm{H}_{2}, \mathrm{He}, \mathrm{H}_{2} \mathrm{O}$ ) can penetrate the structure. 
The physical and chemical properties of zeolites can be improved using several methods like acid treatment and ion exchange. Ion-exchange selectivity changes depending on the crystal structure of zeolite, the cation properties (ionic radius and hydration energy) and ion-exchange states [11, 12]. It was determined by Barrer [13] that analcime features two types of ion-exchange. The first type is the exchange of ions of at room temperature and the second type is the exchange at elevated temperatures. Since analcime has small pores, ion exchange happens more easily when the temperature rises [14]. Barrer and Hinds [14] showed that when Na-analcime is exchanged with transition metals, the amount of silica in zeolites increase. On the other hand, $\mathrm{Co}^{+2}, \mathrm{Ni}^{+2}, \mathrm{Cu}^{+2}$ and $\mathrm{Zn}^{+2}$ ions exchange to a lesser extent with sodium. If a pair of cations is exchanged with analcime, the cation-selection preference is determined by their size. Lower framework charge (high Si/Al) prefers the bigger cation and higher framework charge (low Si/Al) prefers the smaller cation. The exchange of the $\mathrm{Li}^{+}$atom with analcime is difficult due to $\mathrm{Li}^{+}$being very small and possessing high hydration energy. Barrer and Hinds [14] found that at high temperature, $\mathrm{K}^{+}, \mathrm{Ag}^{+}, \mathrm{Ti}^{+}, \mathrm{NH}_{4}{ }^{+}$and $\mathrm{Rb}^{+}$cations exchange easily with $\mathrm{Na}$-analcime, but determined that $\mathrm{Sr}^{+2}, \mathrm{Mg}^{+2}, \mathrm{Co}^{+2}$ and $\mathrm{Ni}^{+2}$ atoms exchange in very small amounts with $\mathrm{Na}$-analcime [15]. The water content of analcime changes linearly with silica content. As the silica content increases, the number of cations decreases and correspondingly the number of water molecules also increases. $\mathrm{Na}^{+}$ cations can be exchanged with alkali metal cations $\left(\mathrm{Li}^{+}, \mathrm{K}^{+}\right), \mathrm{NH}_{4}{ }^{+}, \mathrm{Ag}^{+}$and divalent cations $\left(\mathrm{Ca}^{+2}, \mathrm{Mg}^{+2}\right)$ at high temperatures $\left(225^{\circ} \mathrm{C}\right)$. If the ions are too big, they occupy water locations. For example, when $\mathrm{Na}^{+}$in analcime is replaced with $\mathrm{K}^{+}$or $\mathrm{Cs}^{+}$, the water molecule locations are occupied by alkali metal ions and $\mathrm{H}_{2} \mathrm{O}$ molecules are removed from the structure. Therefore, the degree of hydration changes with the degree of ion exchange [16].

Dehydration-hydration behavior of natural zeolites is important for many application areas and can have many differences, with the zeolite type depending on the nature of interactions between $\mathrm{H}_{2} \mathrm{O}$ molecules and, the Al-Si framework and extra-framework cations. While zeolites that have cavities with structurally large exchange areas like clinoptilolite hydrate easily, zeolites that have small cavities, like analcime, hydrate very slowly [17]. Very slow rehydration of analcime can be attributed to the kinetic diameter $(2.6 \AA)$ of cavities in its structure being smaller than the water molecules (2.65 $\AA)$ [18].

Tuff formations with very significant analcime content in Turkey are located in the areas of Bigadiç (Emirler), Emet (Köpenez), Kırka (Karaören), Urla, Bahçecik-Gölpazarı-Göynük, Nallıhan-ÇayırhanBeypazarı-Mihalıççık, Kalecik-Hasayaz-Şabanözmü-Candır, Polatlı-Mülk-Oğlakçı-Ayaş, Keşan and Gördes [19-22]. But, there are very few works on the thermal and structural characterization of this natural zeolite.

The aim of this work is the determination of the thermal and structural properties of analcime zeolite samples and its cationic forms (HA, FeA, AgA and $\mathrm{CuA}$ ) using XRD, XRF, TG-DTG-DTA and specific surface area measurements.

\section{MATERIALS AND METHODS}

\subsection{Materials and Chemicals}

The analcime sample used in this work was provided from the Çanakkale-Küçükkuyu-Ayvacık area. The sample was ground and sieved to a size less than $45 \mu \mathrm{m}$, using ASTM standard sieves. Cationic forms of analcime were prepared with $1 \mathrm{M} \mathrm{Fe}\left(\mathrm{NO}_{3}\right)_{3} .9 \mathrm{H}_{2} \mathrm{O}$ (FeA), $1 \mathrm{M} \mathrm{AgNO}_{3}(\mathrm{AgA}), 1 \mathrm{M}$ $\mathrm{Cu}\left(\mathrm{NO}_{3}\right)_{2} .3 \mathrm{H}_{2} \mathrm{O}(\mathrm{CuA})$ and $1 \mathrm{M} \mathrm{HCl}(\mathrm{HA})$ solutions in a shaker for 6 hours at $80^{\circ} \mathrm{C}$. After this process, solutions were filtered and the sample was washed seven times with deionized water at boiling point and then dried at room temperature. Before the experimental processes, all samples were dried for 16 hours in a $110^{\circ} \mathrm{C}$ oven and then stored in a desiccator.

The organic chemicals like $\mathrm{HCI}, \mathrm{Fe}\left(\mathrm{NO}_{3}\right)_{3} .9 \mathrm{H}_{2} \mathrm{O}, \mathrm{AgNO}_{3}$ and $\mathrm{Cu}\left(\mathrm{NO}_{3}\right)_{2} .3 \mathrm{H}_{2} \mathrm{O}$ were provided by Merck (Darmstadt, Germany), and all solutions were prepared using deionized water. 


\subsection{CHARACTERIZATION}

The chemical composition of samples was determined using powdered samples fused with lithium tetraborate using X-ray fluorescence (XRF - Rigaku ZSX Primus device). X-ray diffraction (XRD) patterns were obtained with a D8 Advance Bruker AXS instrument, using CuK $\alpha$ radiation $(\lambda=1.54 \AA)$ at intervals $40 \mathrm{kV}$ and $20 \mathrm{~mA}$, in the range 3 to $50^{\circ}(2 \theta)$. TG-DTG-DTA curves were determined at a $10^{\circ} \mathrm{C} \mathrm{min}^{-1}$ heating rate, for a sample of approximately $30 \mathrm{mg}$, using an alumina crucible with a Setsys Evalution Seteram device over a temperature interval of $30^{\circ} \mathrm{C}$ to $1000^{\circ} \mathrm{C}$. Surface areas of the samples were measured at $-196^{\circ} \mathrm{C}$ from $\mathrm{N}_{2}$ adsorption isotherms using the BET method and an Autosorb 1-C volumetric device. Before the adsorption process, zeolites were subjected to a degassing process through exposure to a vacuum at $300^{\circ} \mathrm{C}$ for 7 hours. High purity nitrogen gas $(99.99 \%)$ was used in adsorption measurements.

The BET gas adsorption method is the most common standard method used for calculating the specific surface areas of solids, and it involves the use of the BET equation [23]:

$$
\frac{1}{V\left[\left(P_{0} / P\right)-1\right]}=\frac{1}{V_{m} C}+\frac{C-1}{V_{m} C}\left(\frac{P}{P_{0}}\right)
$$

Here $P_{0}$ is the saturated vapor pressure of the gas over the solid. $P / P_{0}$ is the relative pressure of the adsorbate molecule. $C$ is the BET constant. $V$ is the amount adsorbed gas at the relative pressure $P / P_{0}$ and $V_{m}$ is the monolayer capacity. The BET surface areas of natural and ion-exchanged zeolite samples were calculated at the relative pressure interval of 0.05 to 0.2 , using adsorption isotherms.

\section{RESULTS AND DISCUSSION}

\subsection{Chemical Analysis}

The chemical compositions of the analcime samples in terms of the percentage of oxides are given in Table 1. It is determined that this sample is rich in $\mathrm{Al}_{2} \mathrm{O}_{3}$ and $\mathrm{SiO}_{2}$. It is also seen that $\mathrm{Na}^{+}, \mathrm{Ca}^{+2}$ and $\mathrm{Mg}^{+2}$ cations decrease in analcime zeolites exchanged with heavy metal cations. As shown in Table 1, $\mathrm{Ag}^{+}$cations enter the structure to a large extent as a result of treatment the analcime sample with a $1 \mathrm{M}$ silver nitrate solution. A decrease in the iron, sodium, magnesium and calcium cations, along with aluminum, was detected as a consequence of treatment the analcime with $1 \mathrm{M} \mathrm{HCl}$ acid. Acid treatment increased the $\mathrm{SiO}_{2} / \mathrm{Al}_{2} \mathrm{O}_{3}$ molar ratio from 5.63 to 6.85 by removing aluminum from the zeolite structure. The first purpose of the acid treatment is the removal of impurities and substances like $\mathrm{Fe}_{2} \mathrm{O}_{3}$ from the pores and cavities of zeolite [24].

Table 1. Chemical compositions of natural and modified analcime samples determined using XRF

\begin{tabular}{lccccc}
\hline $\begin{array}{l}\text { Chemical } \\
\text { Analysis (\%) }\end{array}$ & \multicolumn{1}{c}{$\mathrm{A}$} & \multicolumn{1}{c}{$\mathrm{CuA}$} & \multicolumn{1}{c}{$\mathrm{FeA}$} & \multicolumn{1}{c}{$\mathrm{AgA}$} & \multicolumn{1}{c}{$\mathrm{HA}$} \\
\hline $\mathrm{SiO}_{2}$ & 71.992 & 71.599 & 73.125 & 71.086 & 77.148 \\
$\mathrm{Al}_{2} \mathrm{O}_{3}$ & 12.766 & 12.964 & 12.097 & 12.490 & 11.261 \\
$\mathrm{Fe}_{2} \mathrm{O}_{3}$ & 2.409 & 2.405 & 2.767 & 2.365 & 0.761 \\
$\mathrm{MgO}$ & 0.799 & 0.749 & 0.593 & 0.731 & 0.255 \\
$\mathrm{CaO}$ & 0.891 & 0.507 & 0.465 & 0.494 & 0.619 \\
$\mathrm{~K}_{2} \mathrm{O}$ & 5.686 & 5.690 & 5.778 & 5.389 & 5.619 \\
$\mathrm{Na}_{2} \mathrm{O}$ & 1.652 & 1.621 & 1.489 & 0.796 & 1.281 \\
$\mathrm{TiO}_{2}$ & 0.203 & 0.206 & 0.235 & 0.238 & 0.276 \\
$\mathrm{P}_{2} \mathrm{O} 5$ & 0.066 & 0.060 & - & 0.051 & - \\
$\mathrm{CuO}$ & - & 0.669 & - & - & - \\
$\mathrm{Ag}_{2} \mathrm{O}$ & - & - & - & 3.519 & - \\
$\mathrm{LOI}$ & 3.532 & 3.524 & 3.447 & 2.835 & 2.776 \\
\hline
\end{tabular}




\subsection{X-ray Analysis}

XRD patterns were obtained for natural analcime and its ion-exchanged forms (Figures 1-3). As shown in Figure 1, it was determined that the natural zeolite sample includes analcime (A) as the main mineral, and, in addition to that, they also includes quartz $(\mathrm{Q})$, feldspar $(\mathrm{F})$, montmorillonite $(\mathrm{M})$ and amorphous substances. The characteristic diffraction peaks of analcime are determined to be at crystal spacings, $\mathrm{d}=5.60 \AA, 4.85 \AA, 3.43 \AA$ and $2.92 \AA$ in the XRD pattern of natural analcime sample $[25,26]$. No other zeolite type is determined using XRD analysis. Quartz peaks were found at $\mathrm{d}=4.26 \AA$, $3.34 \AA, 2.99 \AA$, $2.46 \AA, 2.28 \AA$ and $2.12 \AA$. Feldspar peaks were seen at $d=3.77 \AA, 3.46 \AA$ and $3.22 \AA$ [27].

From the XRD analysis examination of ion-exchanged analcime zeolites, some changes in the peak intensities are seen (Figures 2 and 3). These changes in the peak intensities can be attributed to changes in the chemical composition of the mineral due to the ion-exchange process (Table 1). While a considerable decrease in the intensity of the peak at $d=5.60 \AA$ is seen in the XRD pattern of HA sample, it is seen that the intensities of the quartz peaks at $\mathrm{d}=4.26 \AA$ and $\mathrm{d}=3.34 \AA$ are largely increased (Figure 2). This was likely related to both dealumination and the partial destruction of the analcime structure. It is also seen that insoluble impurities like quartz and feldspar are left in the structure after the acid process [28]. It is seen however, that while the intensities of the quartz peaks at $\mathrm{d}=3.34 \AA$ of FeA and CuA samples increase by a considerable amount, the analcime peak at $d=5.60 \AA$ from the AgA sample disappears completely and its quartz peak at $\mathrm{d}=3.34 \AA$ has decreased by a considerable amount (Figures 2 and 3). XRD analysis exhibited that considerable change was observed in the crystallinity of natural zeolite after Ag-exchange treatment. This can be related to cation migration and the elimination of water molecules from the structure channels due to heating. Natural zeolites have a good selectivity for silver ions [29].

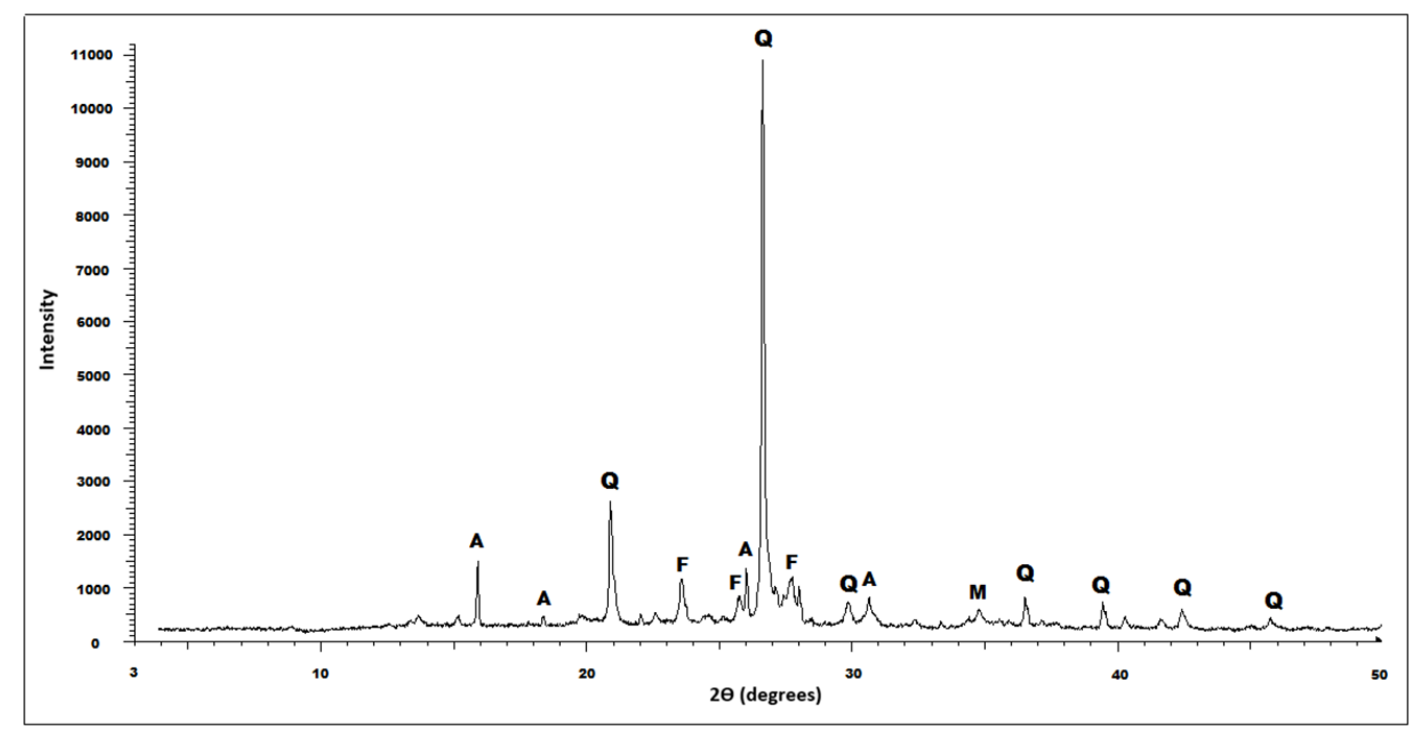

Figure 1. X-ray diffraction pattern of natural analcime sample. (A: Analcime; K: Quartz; F: Feldspar; M: Montmorillonite) 


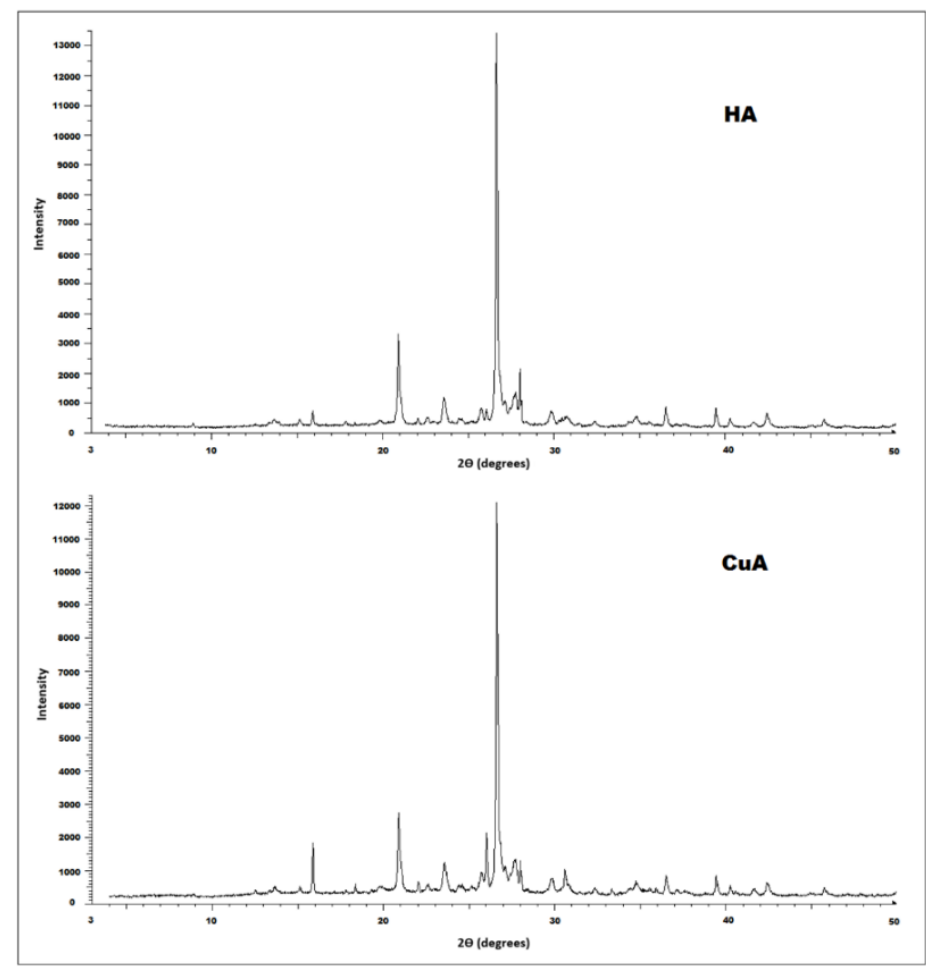

Figure 2. X-ray diffraction pattern of $\mathrm{HA}$ and $\mathrm{CuA}$ samples

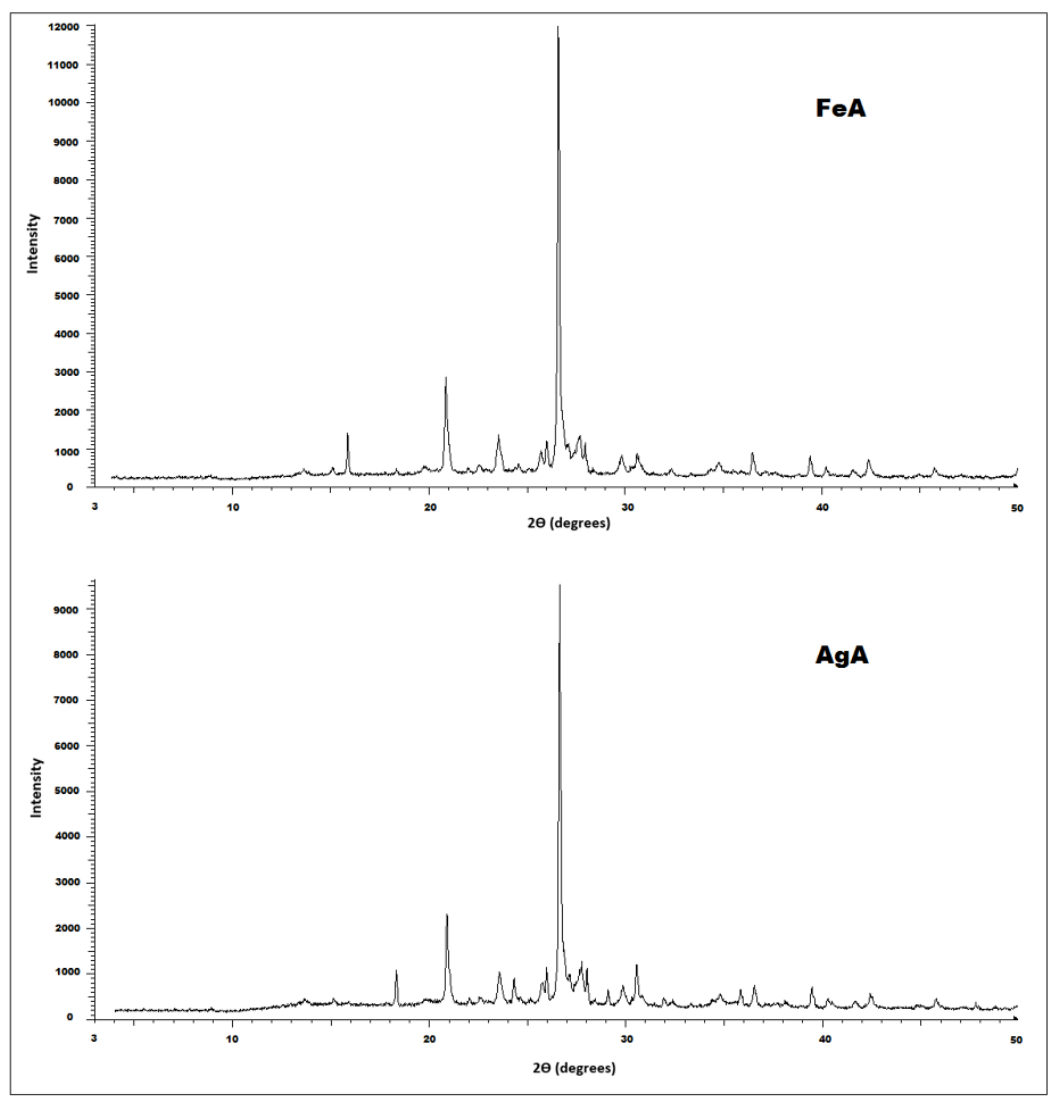

Figure 3. X-ray diffraction patterns of FeA and AgA samples 


\subsection{Thermal Analysis}

Dehydration of analcime is a relatively simple single-step process, since the water molecules occupy at a single distinct location in the crystal structure [8]. Hydration-dehydration thermodynamics of analcime minerals have been examined by many researchers [30-39]. No phase transition has been observed during the dehydration of cubic structured analcime at high temperature [35].

The TG-DTG-DTA curves of analcime samples are shown in Figure 4. The decomposition temperatures of $\mathrm{AgA}$ and $\mathrm{HA}$ samples shifted toward lower temperatures compared with natural analcime. An endothermic peak is observed in the DTA curve of the HA sample at $77^{\circ} \mathrm{C}$. On the other hand, in the DTA curves of natural analcime $\mathrm{A}, \mathrm{CuA}, \mathrm{FeA}$ and $\mathrm{AgA}$ samples, two endothermic peaks are observed. The first endothermic peak is observed at temperatures of $70^{\circ} \mathrm{C}(\mathrm{AgA})$ and $83^{\circ} \mathrm{C}(\mathrm{CuA}$, $\mathrm{FeA}$ and A). A second endothermic peak is observed at temperatures of $466^{\circ} \mathrm{C}(\mathrm{FeA}), 472{ }^{\circ} \mathrm{C}(\mathrm{AgA})$, $480{ }^{\circ} \mathrm{C}(\mathrm{CuA})$ and $481^{\circ} \mathrm{C}(\mathrm{A})$. The first endothermic peak, which is observed up to $20{ }^{\circ} \mathrm{C}$ in the DTA curves of the analcime samples was higher and corresponds to the elimination of physically adsorbed water from the structure. The second endothermic peak, which was observed in a broad temperature interval from $200{ }^{\circ} \mathrm{C}$ to $500{ }^{\circ} \mathrm{C}$ shows a loss of water that is more tightly bound to the structure. Dehydroxylation was observed through the greater loss of water at high temperatures.
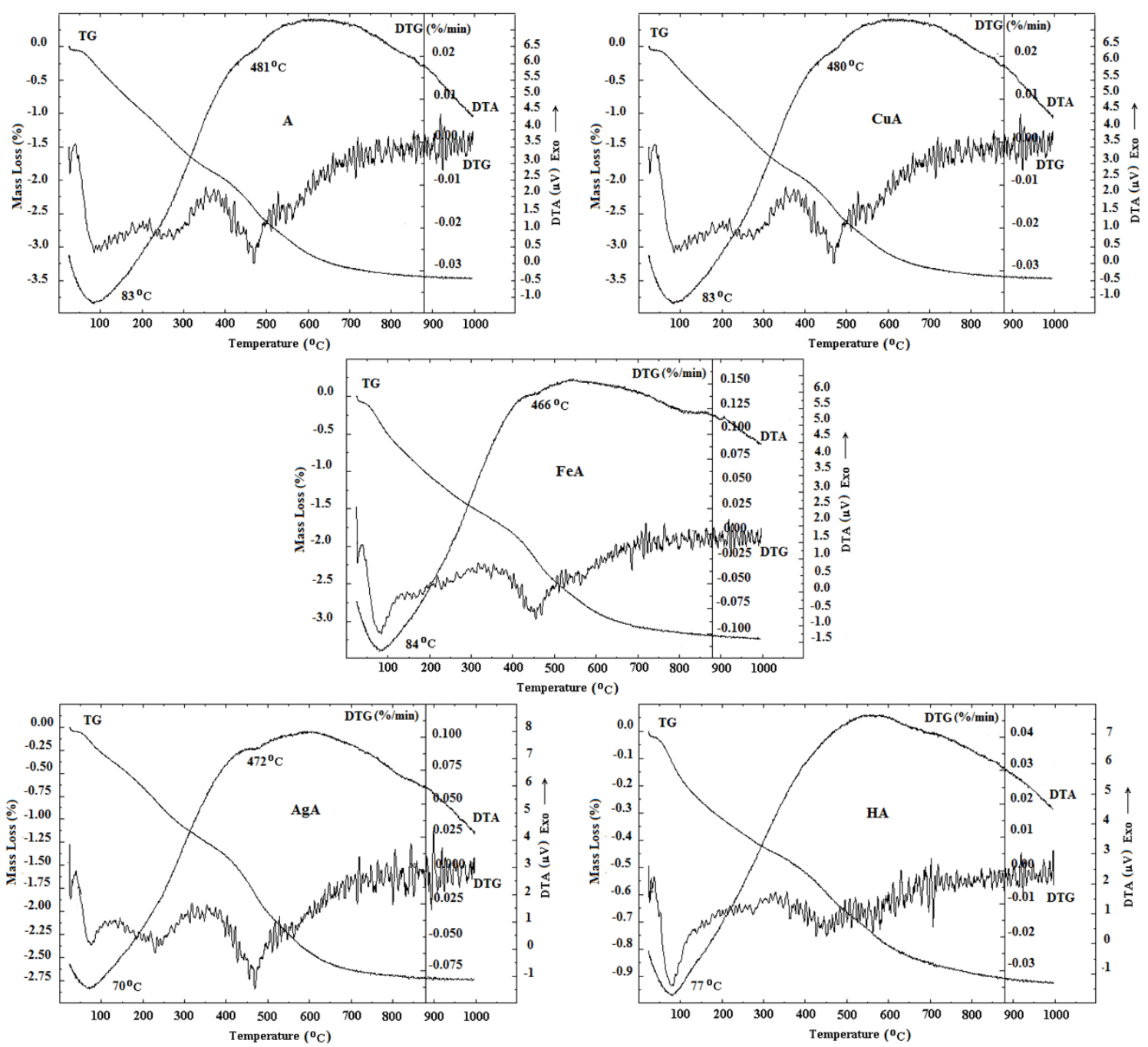

Figure 4. TG-DTG-DTA curves of natural and modified analcime samples 
The temperature intervals and mass loss values determined by TG-DTG analysis are given in Table 2 . It was observed that for a series of heavy metal cation-exchanged forms the thermal stability and water retentivity of natural analcime increased in the order as $\mathrm{Ag}<\mathrm{Fe}<\mathrm{Cu}$. It was determined that the total mass loss of $\mathrm{CuA}, \mathrm{A}, \mathrm{FeA}, \mathrm{HA}$ and $\mathrm{AgA}$ analcime samples at $1000{ }^{\circ} \mathrm{C}$ after TG analysis was $3.46 \%$, $3.30 \%, 3.23 \%, 2.94 \%$ and $2.73 \%$, respectively. It is seen that the total mass loss of natural and modified analcime samples are very close to the values of loss ignition (LOI) (Table 1) of the same samples. It was determined that greater loss of water occurs for the zeolites that are exchanged with divalent cations. In addition to that, it is seen that zeolite, which is exchanged with large, monovalent cations show less water loss (Table 2).

$\underline{\text { Table 2. (\%) Mass loss of analcime samples at different temperature intervals }}$

\begin{tabular}{lccccc} 
Sample & $30-200{ }^{\circ} \mathrm{C}$ & $200-370{ }^{\circ} \mathrm{C}$ & $370-750{ }^{\circ} \mathrm{C}$ & $750-1000{ }^{\circ} \mathrm{C}$ & Tot. (\%) \\
\hline $\mathrm{A}$ & 0.98 & 0.76 & 1.48 & 0.08 & 3.30 \\
$\mathrm{AgA}$ & 0.66 & 0.63 & 1.37 & 0.06 & 2.73 \\
$\mathrm{CuA}$ & 0.97 & 0.90 & 1.50 & 0.10 & 3.46 \\
$\mathrm{FeA}$ & 1.06 & 0.64 & 1.41 & 0.12 & 3.23 \\
$\mathrm{HA}$ & 1.03 & 0.52 & 1.23 & 0.16 & 2.94 \\
\hline
\end{tabular}

\subsection{Surface Area}

Surface area data, correlation coefficients and BET constant $\mathrm{C}$ for natural and modified analcime samples are shown in Table 3. As seen in Figure 5, the adsorption isotherms of analcime samples are type II according to International Union of Pure and Applied Chemistry (IUPAC) classification [40]. It is seen that the specific surface areas of modified analcime samples are bigger than the surface areas of natural zeolite samples (Table 3). The BET surface areas decreased in the sequence $\mathrm{HA}>\mathrm{FeA}>\mathrm{CuA}$ $>\mathrm{AgA}>\mathrm{A}$. The specific surface area of the natural chabazite increased from $10.40 \mathrm{~m}^{2} / \mathrm{g}$ to $25.28 \mathrm{~m}^{2} / \mathrm{g}$ after treatment $1 \mathrm{M}$ iron nitrate solution. The considerable increase in the BET surface area of FeA was ascribed to decationation and dealumination. It is also seen that the smallest surface area belongs to the $\operatorname{AgA}\left(14.60 \mathrm{~m}^{2} / \mathrm{g}\right)$ sample among the analcime samples that are exchanged with heavy metal cations. This decrease in the surface area can be attributed to the partial blockage of the channels in the structure by the $\mathrm{Ag}^{+}(1.26 \AA)$ cations after the analcime was modified by treatment with silver nitrate solution [41].

It is seen that the analcime sample processed with a $1 \mathrm{M} \mathrm{HCl}$ acid solution had the biggest BET specific surface area with respect to the others. The surface area of the natural analcime sample has increased from $10.40 \mathrm{~m}^{2} / \mathrm{g}$ to $41.88 \mathrm{~m}^{2} / \mathrm{g}$ (Table 3). The acid treatment causes the $\mathrm{Al}^{3+}$ atoms to remove from the zeolite structure and zeolite cations to be exchanged with $\mathrm{H}^{+}$. As a result of the removal of aluminum from the structure, important changes occur in the adsorption properties of zeolite. Acid treatment also causes the amorphous substances inside the channels within the structure to remove and new pores to form. If the intensity of the acid process is too high, it may cause partial or total damage to the structure of the zeolite crystal [24, 42-44].

Table 3. Surface areas of natural analcime and its ionic forms

\begin{tabular}{cccc}
\hline Sample Name & $\begin{array}{c}\text { Multi Point BET } \\
\text { Surface Area } \\
\left(\mathrm{m}^{2} / \mathrm{g}\right)\end{array}$ & BET Constant C & $\begin{array}{c}\text { Correlation } \\
\text { Coefficient }\end{array}$ \\
\hline $\mathrm{A}$ & 10.40 & 59.18 & 0.999 \\
$\mathrm{HA}$ & 41.88 & 248.60 & 0.999 \\
$\mathrm{Fe}$ & 25.28 & 174.70 & 0.999 \\
$\mathrm{CuA}$ & 17.66 & 84.60 & 0.999 \\
$\mathrm{AgA}$ & 14.60 & 48.34 & 0.999 \\
\hline
\end{tabular}




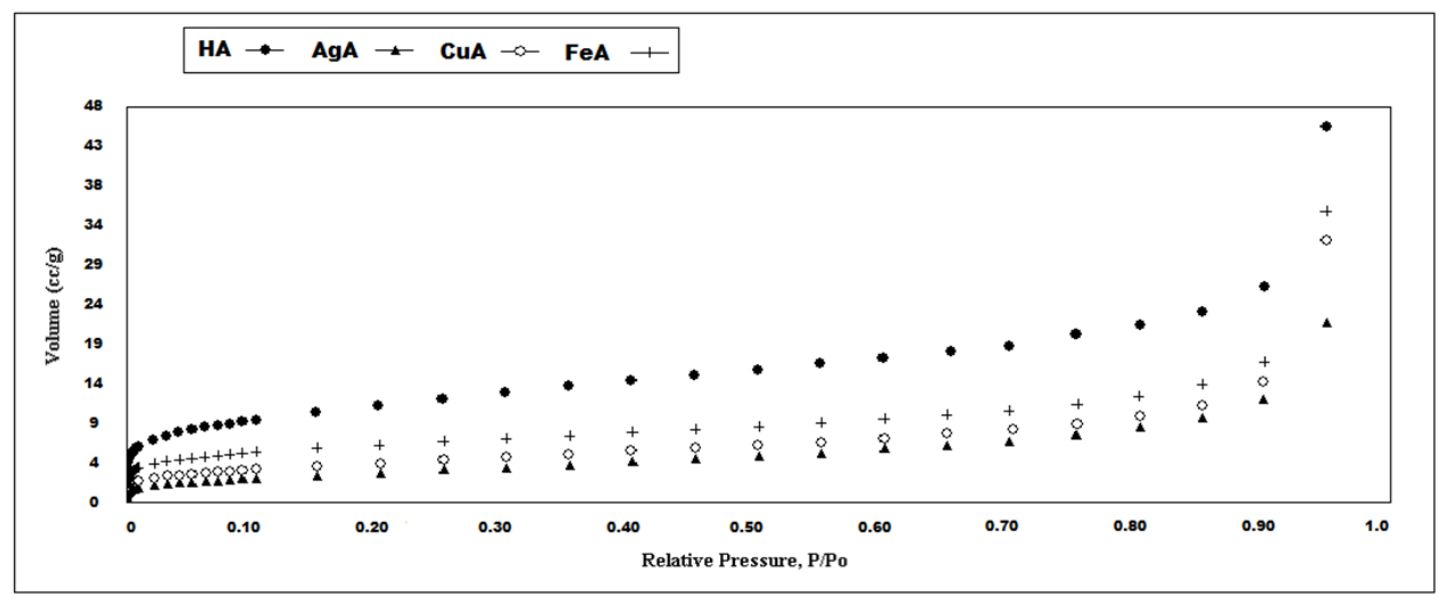

Figure 5. Nitrogen adsorption isotherms of the $\mathrm{Ag}-, \mathrm{Cu}-, \mathrm{Fe}-$ and $\mathrm{H}$-forms of analcime

\section{CONCLUSION}

Natural and ion-exchanged analcime samples were characterized using the XRF, XRD, TG-DTG-DTA and nitrogen adsorption methods. It was determined that the natural zeolite has analcime as the main mineral but also includes quartz, feldspar, montmorillonite and amorphous substances. XRD analysis showed that important changes occurred in the crystal structure of the Ag- and $\mathrm{H}$-forms of analcime. While the analcime peak of AgA disappears completely, the quartz peak intensity decreased by a considerable amount. On the other hand, the analcime peak in the HA sample decreased significantly, while the quartz peak increased by a significant amount.

DTA curves of ion-exchanged analcime zeolites showed that these samples exhibited thermal stability up to high temperatures. However, it is found that the $\mathrm{Ag}$ - and $\mathrm{H}$ - forms of analcime show different thermal properties due to the change in their crystal structure and chemical composition. It was determined that the thermal decomposition temperatures of Ag-exchanged analcime shifted towards lower temperature values compared to natural analcime. This shows that the AgA sample had less thermal stability compared to natural zeolite. On the other hand, the amount of water molecules in the $\mathrm{AgA}$ sample decreased significantly due to the decrease in cations in the analcime structure after the Ag-exchange. Therefore, it was seen that AgA has the least amount of mass loss among the ionexchanged samples. Also, the removal of cations and aluminum from the analcime structure, after treatment with the acid solution, caused a decrease in the hydrophilic nature of HA. This resulted in the $\mathrm{H}$-form of analcime having both a lower endothermic peak temperature, and less mass loss, compared to natural analcime.

It was determined that the surface areas of ion-exchanged analcime zeolites are increased in comparison to natural analcime. It was found that while $\mathrm{AgA}\left(14.60 \mathrm{~m}^{2} / \mathrm{g}\right)$ has the smallest surface area, HA (41.88 $\mathrm{m}^{2} / \mathrm{g}$ ) has the largest surface area of these samples. The decrease in the surface area of the AgA sample can be attributed to the blockage of analcime pores by the $\mathrm{Ag}^{+}$cations during the modification process with the silver nitrate solution. On the other hand, the increase in the surface area of the HA sample can be attributed to the changes in the pore structure by the removal of amorphous substances and aluminum from the analcime structure when treatment with the acid solution.

Consequently, it was seen clearly that the structural, thermal and adsorption properties of analcime samples are affected by the ion-exchange process. The fact that natural zeolite are very cheap, abundant and easily obtained, makes these materials attractive in many application areas. Therefore, the thermal and structural characterization of natural and modified zeolites has great importance. 


\section{REFERENCES}

[1] Shaobin W, Yuelian P. Natural zeolites as effective adsorbents in water and wastewater treatment. Chem Eng J 2010; 156: 11-24.

[2] Taylor W.H. The structure of analcite $\left(\mathrm{NaAlSi}_{2} \mathrm{O}_{6} \cdot \mathrm{H}_{2} \mathrm{O}\right)$. Z Kristallogr 1930; 74: 1-19.

[3] Hurlbut CS, Klein C. Manual of Mineralogy, 20th ed. New York, NY, USA: Wiley, 1985.

[4] Calleri M, Ferraris G. Struttura dellíanalcime: $\mathrm{NaAlSi}_{2} \mathrm{O}_{6} \cdot \mathrm{H}_{2} \mathrm{O}$. Atti Accad Sci Tolrino 1964; 98: 821- 846.

[5] Knowles CR, Rinaldi FF, Smith JV. Refinement of the crystal structure of analcime. Indian Mineral 1965; 6: 127-140.

[6] Ferraris G, Jones DW, Yerkess J. A neutron-diffraction study of the crystal structure of analcime, $\mathrm{NaAlSi}_{2} \mathrm{O}_{6} \cdot \mathrm{H}_{2} \mathrm{O}$. Z Kristallogr 1972; 135: 240-252.

[7] Pechar F. Crystal-chemistry of analcime. Acta Univ Carol Geol 1989; 4: 469-487.

[8] Mazzi F, Galli E. Is each analcime different? Am Mineral 1978; 63: 448-460.

[9] Armbruster T, Gunter, ME. Crystal structures of natural zeoltes, Natural Zeolites: Occurrence, Properties, Applications. In: Bish DL, Ming DW, editors. Mineralogical Society of America Reviews in Mineralogy and Geochemistry, Washington, DC USA, 2001, pp. 1-57.

[10] Hovis GL, Roux J, Rodrigues E. Thermodynamic and structural behavior of analcime - leucite analogue systems. Am Mineral 2002; 87: 523-532.

[11] Semmens M, Seyfarth M. The selectivity of clinoptilolite for certain heavy metals. In: Sand, LB, Mumpton FA, editors. Natural Zeolites: Occurrence, Properties and Use, New York, NY, USA: Pergamon Press; 1978. pp. 517-519.

[12] Ping Y. Use of Natural Zeolites in the Recovery of Metals. Kokkola: Central Ostrobothnia University of Applied Sciences Press, 2010.

[13] Barrer R. Ion-exchange and ion-sieve processes in crystalline zeolites. J Chem Soc 1950; 481: 2341-2348.

[14] Barrer R, Hinds L. Ion-exchange in crystals of analcite and leucite. J Chem Soc 1953; 386: 18771889.

[15] Sudaporn T, Kunwadee R, Alan D. Ion exchange of $\mathrm{Cu}^{2+}, \mathrm{Ni}^{2+}, \mathrm{Pb}^{2+}$ and $\mathrm{Zn}^{2+}$ in analcime (ANA) synthesized from Thai perlite Micropor Mesopor Mater 2005; 79: 171-175.

[16] Jagannadha RM, and Gopal KB. Naturally Engineered Analcime for Water Treatment Process and its Calorimetric Properties. In: NCKITE 2015 National Conference on Knowledge; 10-11 April 2015; Raipur, Chhattisgarh, India: NCKITE. Pp. 160-166.

[17] Chipera SJ, Bish DL. Rehydration kinetics of a natural analcime. Eur J Mineral 2010; 22: 787-795.

[18] Breck DW. Zeolite Molecular Sieves. New York, NY, USA: John Wiley and Sons, 1974. 
[19] Ataman G, Gündoğdu N. Analcimic zones in the Tertiary of Anatolia and their geological positions. Sediment Geol 1982; 31: 89-99.

[20] Esenli F, Özpeker I. Gördes çevresindeki neojen havzasının zeolitik diyajenezi ve höylanditklinoptilolitlerin mineralojisi, Türkiye Jeoloji Kurultayı Bülteni, 1993. pp. 8-18.

[21] Gündoğdu MN, Yalçın H, Temel A, Clauer N. Geological, mineralogical and geochemical characteristics of zeolite deposits associated with borates in the Bigadiç, Emet ve Kırka Neeogene Lacustrine basins, Western Turkey. Miner Deposit 1996; 31: 492-513.

[22] Esenli F, Uz B, Suner F, Esenli V, Ece ÖI, Kumbasar I. Zeolitization of tuffaceous rocks in the Keşan region, Thrace, Turkey. Geologia 2005; 58: 51-161.

[23] Brunauer S, Emmett PH, Teller E. Adsorption of gases in multimolecular layers, J Am Chem Soc 1938; 60: 309-319.

[24] Xing F, Ding H, Feng NQ. The research about activated processing of improving adsorption capacity of natural zeolite. Conservation and Utilization of Mineral Resources 2000; 2: 17-21.

[25] Treacy MMJ, Higgins JB. Collection of Simulated XRD Powder Patterns for Zeolites, 5th ed. Oxford, UK: Elsevier, 2007.

[26] Özen S, Göncüoğlu MC. Origin of analcime in the Neogene Arikli Tuff, Biga Peninsula, NW Turkey. N Jb Miner Abh 2012; 189: 21-34.

[27] McClune WF. Powder diffraction file: inorganic phases. New York, NY, USA: Joint Comittee on Powder Diffraction Standards, 1991.

[28] Ates A, Hardacre C. The effect of various treatment conditions on natural zeolites: Ion exchange, acidic, thermal and steam treatments, J Colloid Interf Sci 2012; 372: 130-140.

[29] Ahmad ZB, Dyer A. Ion exchange in near-homoionic ferrierites. In: Kallo D, Sherry HS, editors. Occurrence, Properties, and Utilization of Natural Zeolites. Budapest, Hungary: Akademiai Kiada, 1988. pp. 431-448.

[30] King EG. Low temperature heat capacity and entropy at $298.16 \mathrm{~K}$ of analcite. J Amer Chem Soc 1955; 77: 2192-2193.

[31] King EG, Weller WW. Low temperature heat capacity and entropy at $298.15 \mathrm{~K}$ of some sodiumand calcium-aluminum silicates. U.S. Bureau of Mines, Report of Investigations, 1961.

[32] Robie RA, Hemingway BS, Fisher J.R. Thermodynamic properties of minerals and related substances at $298.15 \mathrm{~K}$ and 1 bar (105 Pascals) pressure and at higher temperatures. U.S. Geological Survey Bulletin, 1979, pp. 1452-1456.

[33] Helgeson HC, Delany JM, Nesbitt HW, Bird DK. Summary and critique of the thermodynamic properties of rock-forming minerals. Am J Sci 1978; 278A: 1-229.

[34] Johnson GK, Flotow HE, O'Hare PAG, Wise WS. Thermodynamic studies of zeolites: analcime and dehydrated analcime. Am Mineral 1982; 67: 736-748.

[35] Line CM. The behavior of water in analcime, $\mathrm{NaAlSi}_{2} \mathrm{O}_{6} \cdot \mathrm{H}_{2} \mathrm{O} . \mathrm{PhD}$, Department of Earth Science, University of Cambridge, UK, 1995. 
[36] Line CM, Putnis A, Putnis C, Giampaolo C. The dehydration kinetics and microtexture of analcime from two parageneses. Am Mineral 1995; 80: 268-279.

[37] Ogorodova LP, Kiseleva IA, Melchakova LV, Belitskii IA, Fursenko BA. Enthalpies of formation and dehydration of natural analcime. Geochem Int 1996; 34: 980-984.

[38] Kim Y, Kirkpatrick RJ. High-temperature multi-nuclear NMR investigation of analcime. Am Mineral 1998; 83: 339-347.

[39] Bish DL, Carey JW. Thermal behavior of natural zeolites. In: Bish DL, Ming DW, editors. Natural Zeolites: Occurrence, Properties, Applications. Mineralogical Society of America, Washington DC: 2001, pp. 403-452.

[40] Mumpton FA. Natural Zeolites, In: Mumpton FA, editor. Mineralogy and Geology of Natural Zeolites. New York, NY, USA: 1977. pp. 1-18.

[41] Munakata K. Adsorption of Nobele Gases on Siver-mordenite. J Nucl Sci Technol 2003; 40: 695697.

[42] Elaiopoulos K, Perraki Th, Grigoropoulou E. Mineralogical study and porosimetry measurements of zeolites from Scaloma area, Thrace, Greece. Micropor Mesopor Mater 2008; 112:441-449.

[43] Elaiopoulos K, Perraki Th, Grigoropoulou E. Monitoring the effect of hydrothermal treatments on the structure of a natural zeolite through a combined XRD, FTIR, SEM and $\mathrm{N}_{2}$-porosimetry analysis. Micropor Mesopor Mater 2010; 134: 29-43.

[44] Akimkhan MA. Structural and Ion-Exchange Properties of Natural Zeolite. In: Ayben K, editor. Ion Exchange Technologies. In Tech press, 2012. pp. 261-282. 